\title{
Laparoscopic resection versus myolysis in the management of symptomatic uterine adenomyosis: alternatives to conventional treatment
}

\author{
Wachyu Hadisaputra, T. Dewi Anggraeni
}

\begin{abstract}
Abstrak
Dalam kurun waktu Juni 2003 sampai dengan Juni 2004, pasien-pasien yang menderita adenomiosis berdasarkan ultrasonografi transvaginal dan memiliki keluhan menorhagia, dismenore, maupun nyeri pelvis diikutsertakan dalam penelitian. Randomisasi dilakukan untuk mengalokasikan subjek ke dalam kelompok reseksi dan kelompok miolisis. Semua pasien dari kedua kelompok mendapat GnRH analog 3 siklus pasca-laparoskopi operatif. Penilaian dilakukan dalam jangka waktu 6 bulan, baik secara subjektif melalui kuesioner maupun secara objektif melalui evaluasi volume adenomiosis per ultrasonografi transvaginal di akhir semester. Terdapat 20 pasien yang menjalani pembedahan, 10 dalam kelompok reseksi dan 10 dalam kelompok miolisis. Komplikasi bermakna tidak ditemukan pada kedua kelompok. Evaluasi subyektif dapat dilakukan pada semua pasien sedangkan evaluasi objektif hanya dapat dilakukan pada 17 pasien. Tidak didapatkan perbedaan bermakna antar-kelompok dalam penurunan skor keluhan menorhagia $(p=0.399)$ dan dismenorea $(p=0.213)$. Tidak ditemukan perbedaan bermakna dalam median penambahan volume adenomiosis $(p=0.630)$ antara kelompok reseksi (median $=+15,35 \%(-100-159))$ dengan kelompok miolisis (median $=+48,43 \%(-100-553)$ ). Lima pasien hamil, 3 dari kelompok reseksi, 2 dari kelompok miolisis, dengan satu kasus ruptur uteri pada usia kehamilan 8 bulan pada kelompok miolisis. Efektifitas reseksi adenomiosis per laparoskopi tidak berbeda bermakna dengan miolisis adenomiosis per laparoskopi dalam penataksanaan adenomiosis bergejala. Miolisis tidak disarankan bagi wanita yang masih ingin hamil. (Med J Indones 2006; 15:9-17)
\end{abstract}

\begin{abstract}
Effective therapy preserving reproductive function in adenomyosis is warranted. From June 2003 to June 2004, patients diagnosed as having adenomyosis by transvaginal ultrasound and had symptoms of menorrhagia, dysmenorrhea, and pelvic pain were randomly allocated to either receive laparoscopic resection or myolysis. GnRH analog was given for 3 cycles after surgery. Within 6 months, symptoms were evaluated using questionnaires and at the end of follow up, adenomyosis volume was assessed by transvaginal ultrasound. There were 20 patients included, 10 patients had resection and the rest underwent myolysis. Both procedures did not yield significant complications. Subjective evaluation by questionnaires was done in all patients. Three patients could not be evaluated objectively by transvaginal ultrasound, 2 patients resigned and 1 was pregnant. There was no significant difference in menorrhagia and dysmenorrhea reduction score between the 2 groups ( $p=0.399$ and 0.213 , respectively). In both groups, dysmenorrhea was reduced significantly after treatment. No significant statistical difference was found in median adenomyosis volume increment ( $p=0.630)$ between the resection (median $=+15.35 \%(-100-159)\}$ and myolysis groups (median $=+48.43 \%(-100-553)$ ). Five patients were pregnant, 3 from the resection group and 2 from the myolysis group. Uterine rupture was found in 1 patient (from the myolysis group) at the age of 8 months of pregnancy. The effectiveness of laparoscopic adenomyosis resection was not significantly different compared with laparascopic myolysis as an alternative conservative surgery in treating symptomatic adenomyosis. Myolysis was not recommended for women who wish to be pregnant. (Med J Indones 2006; 15:9-17)
\end{abstract}

Keywords: laparascopy, resection, myolysis, conservative surgery, symptomatic adenomyosis

Adenomyosis is a benign invasion of the endometrium into the myometrium through lymphatic or vascular duct resulting in diffuse enlargement of the uterus. Microscopically, it is seen as the presence of ec-

Department of Obstetrics and Gynecology, Faculty of Medicine, University of Indonesia / Dr. Cipto Mangunkusumo Hospital, Jakarta, Indonesia topic and non-neoplastic endometrial gland and stroma surrounded by hypertrophic and hyperplastic myometrium. ${ }^{1-3}$ To date, the etiology of this disease has not been clearly elucidated. However, several pathophysiological mechanisms have been proposed, such as damage of endometrial-myometrial border due to trauma and high estrogen biosynthesis associated with increased activities of aromatase enzyme. $^{1,4}$ The incidence rate of the disease varies be- 
tween 5 and 70\%. Generally it occurs in women aged between 40 and 50 years with prevalence rate of 70 $80 \% .^{5-7}$ Adenomyosis was found in $23 \%$ of uterus which has been removed due to fibroma uteri. ${ }^{8}$

Adenomyosis constitutes the primary cause of infertility. ${ }^{4}$ Classical symptoms include menorrhagia (40$50 \%$ ), dysmenorrhea (15-30\%), and pelvic pain (15$25 \%)$. Other common symptoms are enlarged uterus, dyspareunia, suprapubic pain, and lower abdominal pain. The severity of the disease is generally associated with the severity of symptoms. ${ }^{1,59}$ However, in onethird of women the condition was asymptomatic., ${ }^{1,5}$

The conventional and definitive management of symptomatic adenomyosis is hysterectomy. ${ }^{2}$ It is estimated that in the United States approximately 650,000 hysterectomies were performed each year, ${ }^{6}$ with copious menstrual blood as the most frequent indications (20\%). Nevertheless, problems arise with young women who still want to retain their reproductive functions. Drug therapy can be effective in controlling symptoms, but coexistence of endometriosis is frequently encountered and the limited number of controlled trials make the evaluation of drug effectiveness is difficult.

Wood's study showed that conservative surgeries, such as endometrial ablation, myometrial electrocoagulation, or laparoscopic excision were effective in $>50 \%$ of patients, although the follow-up was limited to three years. The pre-operative administration of GnRH resulted in the average reduction in uterus volume by $50.8 \%$, while post-operative administration resulted in average reduction of $14.9 \%{ }^{8}$ However, except for clearly-defined adenomyosis, such as adenomyoma, it is difficult to ensure recovery after excision or electrocoagulation. When uterus is preserved, there are uncertainties concerning the size of myometrium removed, the rate of recurrence, disappearance of symptoms, and whether pregnancy and normal birth are still possible. ${ }^{8}$ To our knowledge, studies comparing the effectiveness of the aforementioned techniques are still limited. Therefore, we conducted a study to compare the effectiveness of laparasopic resection versus myolysis, both were supplemented with post-operative $\mathrm{GnRH}$ administration, in the treatment of symptomatic adenomyosis.

\section{METHODS}

This study was a randomized trial comparing the effectiveness of myolysis versus adenomyosis resection by laparoscopy in eliminating subjective symptoms, such as menorrhagia, dysmenorrhea, and pelvic pain as well as objective signs such as reduced size of adenomyosis.

During the period of June 2003 to June 2004, adenomyosis patients aged between 25-45 years who had symptoms of menorrhagia, dysmenorrhea, and pelvic pain were consecutively recruited at The Reproductive Clinic of Raden Saleh, YPK Maternity Hospital, and Bunda Hospital. Diagnosis was established by transvaginal ultrasonography. Randomization was done to allocate subjects to myolysis or resection group.

\section{Surgical techniques}

\section{Myolysis of adenomyosis by laparoscopy}

We used the electrodes of bipolar sharp forceps for myolysis. The posterior surface of adenomyosis was visualized continuously to protect the rectum, bladder, colon, and uterine blood vessels. The electrodes of bipolar forceps was put directly opposite to adenomyosis so the the depth of penetration could be visualized and damages of colon and bladder could be prevented. After the depth for safe penetration had been determined, the electrodes were applied to adenomyosis at continuous power of 40-50 watts and then moved slowly to reach maximum coagulation. Fiber tip was cooled down by flowing fluid continuously. Excessive blood was suctioned and the tissue was cleaned up thoroughly. Adhesive barrier of interced Tc7 was administered to prevent adhesion.

\section{Laparoscopic resection of adenomyosis}

We used monopolar needle for resection. Like in myolysis technique, the posterior surface of adenomyosis was visualized continuously using valtchev manipulator to protect the rectum, bladder, colon, and uterine blood vessels. The monopolar needle was applied directly opposite to adenomyosis to visualize the depth of penetration so that damages of colon and bladder could be avoided. The borders of adenomyosis were determined by changes in structure, vascularity, or consistency. After the depth of safe penetration had been determined, the electrodes was applied to the adenomyosis using one way current at 100 watts continuous power. Excision was performed slowly to cutout all adenomyosis surface completely. Fluid was flown continuously to cool down the fiber tip. Bleeding was controlled using bipolar needle. After that, we performed approximation of excision wounds by conti- 
nuous suturing. Excessive blood was suctioned and the tissue was cleaned up thoroughly. To prevent adhesion, we administered adhesive barrier of Intercede Tc7.

\section{Post-operative follow-up and evaluation}

After the surgical procedure, we observed the subjects for 24 hours. If their conditions were stable, they were discharged in the next day. We gave antibiotics and NSAID for 3 to 5 days and informed that stomach cramp or post-operative bleeding might occur. They were asked to come back to the hospitals if the cramp or bleeding became severe. If the symptoms could be overcome by medications, subjects could carry out normal activities in the next day. All subjects received GnRH analog therapy for 3 cycles. During the sixmonth follow up, they were requested to write down their subjective symptoms. At the end of follow up transvaginal ultrasonography was done by two fetomaternal counselors to assess the reduction of adenomyosis volume and the subjective symptoms were evaluated. The reduction of menorrhagia was evaluated by measuring the number of pads used or by the length of its use i.e., $\leq$ or $>6$ days. Dysmenorrhea was assessed on the basis of loss of efficiency and the need for bed rest, while pelvic pain was evaluated based on analgesic drugs needed.

\section{RESULTS}

During the study period, 20 subjects underwent conservative surgeries for symptomatic adenomyosis, 10 patients in the resection group and 10 patients in the myolysis group. Significant complications did not occur in both groups. Subjective symptoms could be evaluated in all patients while ultrasonographic reexamination could only be done in 17 patients because two patients resigned from the study and one became pregnant before the time of the evaluation. Baseline characteristics of the subjects are depicted in Table 1, which were comparable between the groups.

Table 1. Baseline characteristics of study subjects

\begin{tabular}{|c|c|c|c|c|}
\hline \multicolumn{2}{|c|}{ Baseline characteristics } & \multicolumn{2}{|c|}{ Group } & \multirow[t]{2}{*}{$\overline{\mathbf{N}}$} \\
\hline & & Resection & Myolysis & \\
\hline \multirow[t]{5}{*}{ Age } & $25-30$ & - & 2 & 2 \\
\hline & 31-35 & 5 & 4 & 9 \\
\hline & $36-40$ & 2 & 3 & 5 \\
\hline & $41-45$ & 1 & 1 & 2 \\
\hline & Mean age & $37.7 \pm 7.7$ & $34.3 \pm 4.6$ & \\
\hline \multirow[t]{4}{*}{ Parity } & $\mathbf{0}$ & 6 & 9 & 15 \\
\hline & 1 & - & 1 & 1 \\
\hline & 2 & 3 & - & 3 \\
\hline & $\mathbf{3}$ & 1 & - & 1 \\
\hline \multirow[t]{3}{*}{ Symptoms } & Menorrhagia & 6 & 6 & 12 \\
\hline & Dysmenorrhea & 10 & 8 & 18 \\
\hline & Pelvic pain & 3 & 3 & 6 \\
\hline \multirow[t]{15}{*}{ Symptom scores } & Menorhagia & & & \\
\hline & 0 & 4 & 4 & 8 \\
\hline & 1 & 5 & 4 & 9 \\
\hline & 2 & - & - & - \\
\hline & 3 & 1 & 2 & 3 \\
\hline & Dysmenorrhea & & & \\
\hline & 0 & 2 & - & 2 \\
\hline & 1 & 5 & 2 & 7 \\
\hline & 2 & 2 & 2 & 4 \\
\hline & 3 & 1 & 6 & 7 \\
\hline & Pelvic pain & & & \\
\hline & O & 8 & 7 & 15 \\
\hline & 1 & - & - & - \\
\hline & 2 & 1 & 1 & 2 \\
\hline & 3 & 1 & 2 & 3 \\
\hline \multirow[t]{2}{*}{ Adenomyosis volume } & Median (range) & $76.85(15-799)$ & $130.5(32-499)$ & \\
\hline & Mean (SD) & $153.42(238.02)$ & $191.11(166.38)$ & \\
\hline
\end{tabular}


In this study, mean age in the resection group was 37.7 (SD 5.7), ranged from 32 to 48 years. In the myolysis group, the mean age was 34.3 (4.6) years, ranged from 28 to years. Most patients were in the age group of 31-35 years (5/10 and 4/10 in myolysis and resection groups respectively) and nullipara.

Table 1 also shows the distribution of subjective symptoms such as menorrhagia, dysmenorrhea, and pelvic pain. The most frequently found symptom was dysmenorrhea which was experienced by 18 of 20 patients, 10 was in the resection group and 8 in the myolysis group.

\section{Comparison of subjective symptoms and adeno- myosis volume between the groups after surgery}

There were no significant statistical differences in symptom scores between the groups after surgery as displayed in Table 2. After the intervention, mean adenomyosis volumes in the resection group was $252.93 \pm 427.45(\mathrm{x} \pm \mathrm{SD}) \mathrm{mm}^{3}$, with median of 92.5 (0-1203), and in the myolysis group $288.00 \pm 247.46$ ( \pm SD), with median of 288 (0-684). Based on Mann-Whitney statistical test, no significant differ- ence was found in median adenomyosis volume between the two groups $(\mathrm{p}=0.277)$.

\section{Comparison of median percentage reduction in symptom scores and in adenomyosis volume be- tween resection and myolysis groups}

Table 3 shows that dysmenorrhea was the most reduced symptom in both groups, i.e. $100 \%$ in the resection group (0-100) with a mean of $75 \%(75 \pm 46.291$ percent), while in the myolysis group $66.6 \%(0-100)$ with a mean of $58.31 \%(58.31 \pm 37.881$ percent $)$. On the other hand, there was no change in the symptom of menorrhagia after intervention either in the resection or in the myolysis group, with a median of $0 \%$ $(0-100)$ and mean of $33.3 \%(33.3 \pm 51.64)$ and a median of $0 \%(0-67)$ and a mean of $11.1 \%(11.1 \pm 27.189 \%)$, respectively. In addition, no statistically significant difference was found in the reduction of menorrhagia and dysmenorrhea scores between the groups ( $\mathrm{p}=0.213$ and $\mathrm{p}=0.399$, respectively). The symptom of pelvic pain could not be analyzed statistically due to the small number of subjects experienced that symptom.

Table 2. Comparison of subjective symptoms and adenomyosis volume between the groups after surgery

\begin{tabular}{|c|c|c|c|c|c|}
\hline \multicolumn{2}{|c|}{ Variables } & \multicolumn{2}{|c|}{ Group } & \multirow[t]{2}{*}{ Total } & \multirow[t]{2}{*}{$\mathbf{P}$} \\
\hline & & Resection & Myolysis & & \\
\hline \multirow[t]{15}{*}{ Symptom scores } & Menorhagia & & & & $0.988^{*}$ \\
\hline & 0 & 6 & 4 & 10 & \\
\hline & 1 & 4 & 5 & 9 & \\
\hline & 2 & - & - & - & \\
\hline & 3 & - & 1 & 1 & \\
\hline & Dysmenorrhea & & & & $0.164 *$ \\
\hline & $\mathbf{0}$ & 3 & 3 & 6 & \\
\hline & $\mathbf{1}$ & 1 & 4 & 5 & \\
\hline & 2 & - & 1 & 1 & \\
\hline & 3 & 1 & 2 & 3 & \\
\hline & Pelvic pain & & & & $1.000 *$ \\
\hline & $\mathbf{0}$ & 8 & 7 & 15 & \\
\hline & 1 & - & 1 & 1 & \\
\hline & 2 & 1 & 2 & 3 & \\
\hline & 3 & 1 & - & 1 & \\
\hline \multirow[t]{2}{*}{ Adenomyosis volume } & Median (range) & $92.5(0-1203)$ & $288(0-684)$ & & 0.277 ** \\
\hline & Mean (SD) & $252.93(427.45)$ & $288.00(247.46)$ & & \\
\hline
\end{tabular}

*Kolmogorove-Smirnov test

**Mann-Whitney test 
Table 3. Comparison of median percentage reduction in symptom scores and changes in adenomyosis volume (\%) between resection and myolysis groups

\begin{tabular}{|c|c|c|c|c|c|c|c|}
\hline \multirow[t]{2}{*}{ Variables } & \multicolumn{3}{|c|}{ Resection } & \multicolumn{3}{|c|}{ Myolysis } & \multirow[t]{2}{*}{$\mathbf{P}$} \\
\hline & $\mathbf{N}$ & Median & Range & $\mathbf{N}$ & Median & Range & \\
\hline Reduced menorrhagia & 6 & .00 & $0-100$ & 6 & .00 & $0-67$ & $0.399 *$ \\
\hline Reduced dysmenorrhea & 8 & 100.00 & $0-100$ & 10 & 66.60 & 0.100 & $0.213 *$ \\
\hline Reduced pelvic pain & 2 & .00 & 0 & 3 & 66.60 & $33-100$ & - \\
\hline Changes in adenomyosis volume & 8 & +13.35 & $-100-159$ & 9 & +48.43 & $-100-553$ & $0.630 *$ \\
\hline
\end{tabular}

* Mann-Whitney test

In this study, we found that generally the volume of adenomyosis was not reduced; instead it enlarged during the period of six-month evaluation. In the resection group, the median (range) of enlargement was $+15.35 \%$ (-100-159) with a mean of $29.57 \%$ (29.57 \pm 76.84 percent), while in the myolysis groups it was $+48.43 \%(-100-553)$ with a mean of $84.91 \%(84.91 \pm$ 194.60 percent). Although it seems that myolysis resulted in greater enlargement than resection did, there was no significant stastitical difference found $(\mathrm{p}=0.630$ ).

\section{Outcomes of surgery, pregnancy, adhesion, side effects, and histopathological findings}

In this study, we suspected adhesion after intervention by transvaginal ultrasonographic examination in 2 patients, 1 from the resection group and the other from the myolysis group. Five patients became pregnant, three of which were from the resection group, and two from the myolysis group, with one patient experienced uterine rupture at 8 months of pregnancy. Early membrane rupture was found in one patient in the resection group.

\section{Outcomes in the resection group}

Of three patients in the resection group who became pregnant, one was 33 years old and had had primary infertility for five years and abortion for two times. This patient showed a reduced volume of adenomyosis up to $3.7 \%$, became pregnant after 13 months postintervention and had her pregnancy terminated by cesarean section at 38 weeks of gestation due to the transverse lie of the fetus. Her baby had birth weight of 3,500 grams. The patient experienced neither any symptom nor complication during pregnancy. Another patient had an age of 34 years with two parities. Her adenomyosis volume was reduced by $3.33 \%$ and she was pregnant for five weeks after 11 months post- surgery. She also experienced reduction in menorrhagia and dysmenorrhea up to $100 \%$. The other patient aged 37 years with primary infertility of 1.5 years became pregnant for 30 weeks in four months after the intervention such that no evaluation of adenomyosis volume could be made.

In this group, two patients had reduction in adenomyosis volume up to $100 \%$; of these, one had adenomyoma on histopathological examination. Four patients had their adenomyosis volume increased up to $159 \%$ with persistent dysmenorrhea and pelvic pain. One 48 year-old patient who had the largest initial volume of adenomyosis $\left(799 \mathrm{~mm}^{3}\right)$ with symptoms of menorrhagia, dysmenorrhea, and pelvic pain, experienced an increased volume by $50.59 \%\left(1203 \mathrm{~mm}^{3}\right)$. Moreover, a suspected adhesion at ultrasonographic examination was found with persistent severity of symptoms in which she had to continue consuming strong analgesics prior to menstruation each month.

\section{Outcomes in the myolysis group}

Of two patients in this group who became pregnant, one was 40 years old; she experienced reduction in adenomyosis volume and dysmenorrhea up to $99.88 \%$ and $100 \%$, respectively, and was pregnant for 20 weeks at 12 months after the intervention. The other patient was 32 years old with primary infertility of 1.5 years. She had a reduced volume of adenomyosis up to $12.5 \%$, and was pregnant in 7 months after intervention. Unfortunately, she had uterine rupture at eight-month pregnancy during the lung maturation period preceded with lower abdominal pain for 1 week and early membrane rupture. Cesarean section was performed in this patient, but the baby died.

One patient experienced reduction in adenomyosis volume and dysmenorrhea score up to $72.7 \%$ and $66.6 \%$, respectively. Six patients had increased adenomyosis volume with the largest being 553\% occur- 
ring in patient aged 31 years with primary infertility for five years. During surgery, very severe adhesion was found in the internal genitalia of this patient and adhesiolysis was performed. Her dysmenhorrhea score was reduced to $66.6 \%$, while the menorrhagia was persistent.
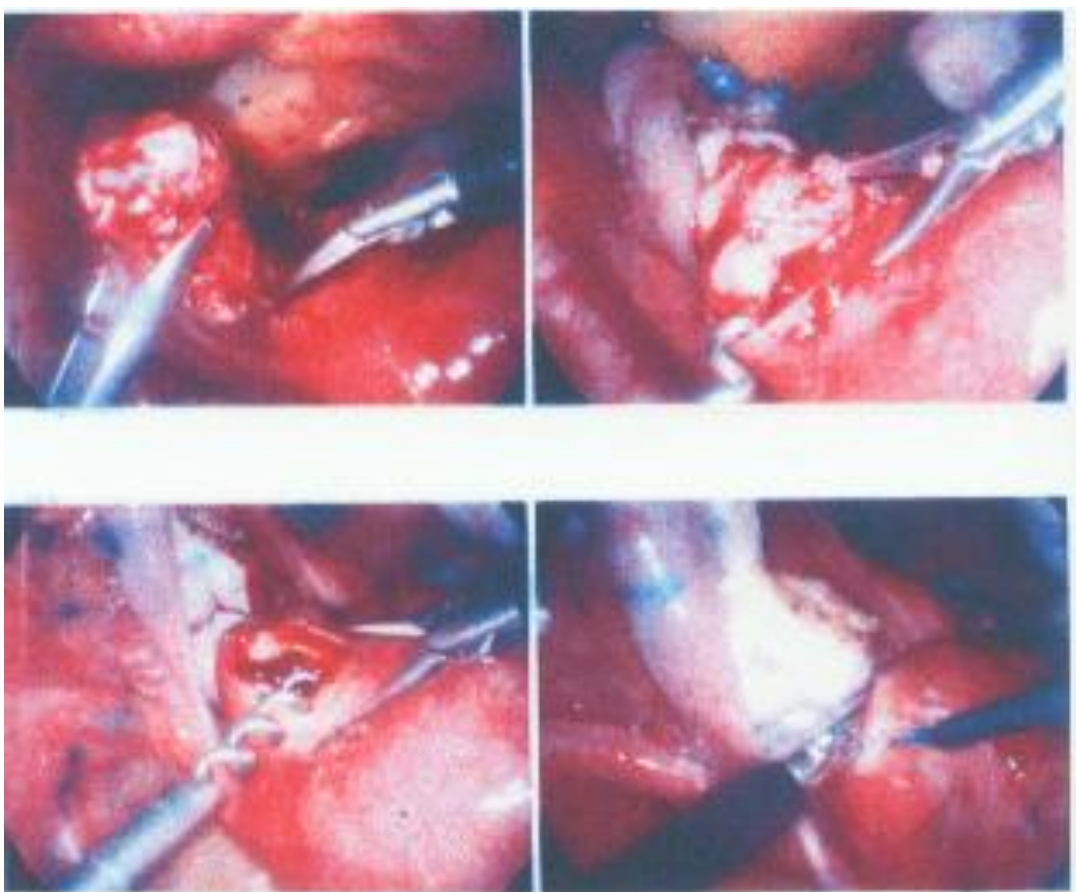

Figure 1. Adenomyosis resection performed in this study
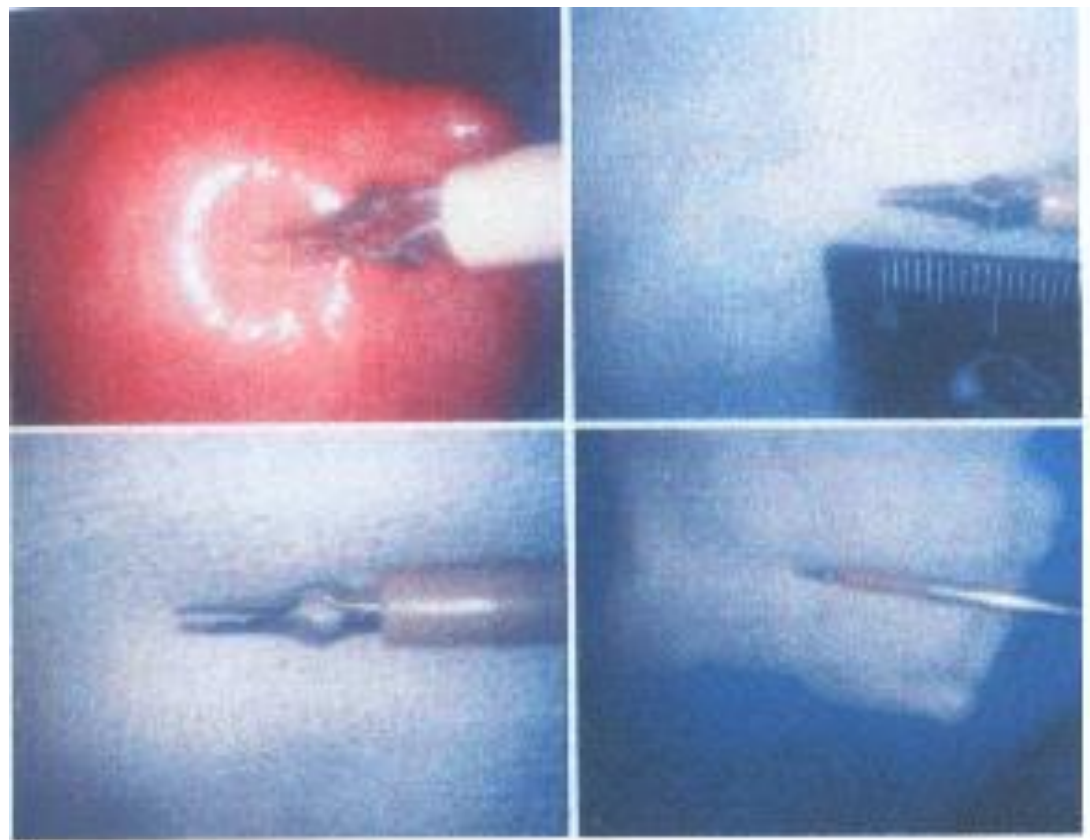

Figure 2. Modification of bipolar sharp forceps used for myolysis in this study (photo by Hadisaputra W) 


\section{DISCUSSION}

\section{Shortcomings of the study}

This study was limited by the small number of subjects, just enough to fulfill the minimum number required for statistical test. As a result, the strength of the study was relatively low and the findings could not be generalized. This study constituted only a preliminary report aiming to obtain data and hypothesis for further study.

Ultrasonographic examinations were performed by two personnel with an assumption that they had equal capabilities and high agreement. However, kappa value was not obtained, so disagreement causing biased results was still possible.

\section{Age and parity in adenomyosis}

In this study, we found that the mean age of patients with adenomyosis was $37.7 \pm 5.7$ in the resection group and $34.3 \pm 4.6$ in the myolysis group with a range of $28-48$ years. This was slightly different from previous studies suggesting that generally adenomyosis occurs in fourth to fifth decades. ${ }^{5-7}$

Seventy-five percent of our patients were nuliparous with a history of two-time abortion in one patient. However, several literature stated that usually adenomyosis patients are multiparous and there is a correlation between a history of inappropriate curettage and the occurrence of this disease. ${ }^{1,4}$ A study conducted in rats showed that adenomyosis could be stimulated by high-dose estrogen and progesterone. In similar physiological condition happening during pregnancy, the infiltration of endometrium into myometrium would be easy. ${ }^{12}$ This finding at least partly explain why histological diagnosis of adenomyosis mostly was found in multiparous women. ${ }^{12}$

However, one literature study suggested that although adenomyosis is generally considered as a typical disease of multiparous women at the end of their reproductive period, disorder of endometrio-myometrial junctional zone can be discovered in young, nuliparous women with symptom of menorrhagia or hypermenorrhea. Here, the disorder of the zone is directly attributed to endometrial factors and indirectly caused by increased response of local immunity. This zone disorder served as predisposing factor for secondary infiltration from endometrial elements, leading to su- perficial adenomyosis. ${ }^{12}$ In the study conducted by Wood, clinical appearance was found in patients aged 24-52 years, with parity of $0-5$, in which infertility was in 12 of 54 patients. $^{8}$

\section{Comparison of subjective symptoms reduction be- tween resection and myolysis}

In this study, symptoms mostly found was dysmenorrhea $(50 \%)$, which was different from some literature which found menorrhagia as the most frequent symptom followed by dysmenorrhea. ${ }^{1,5,9}$ However, this finding was similar to a study by Jacoeb performed in clinical setting. ${ }^{10}$

This study found that either resection or myolysis was equally effective in reducing symptoms, which was similar to Wood's study. However, the success rate reached in this study was lower, in which reduction obtained was $41.2 \%$ by resection and $39.5 \%$ by myolysis, compared to that of Wood's study which was $>50 \%$. This difference may be due to the fact that the recurrence rate in our subjects was reasonably high, as evident from the increase in adenomyosis volume after intervention in both groups, i.e. $15.35 \%(-100-$ $159)$ and $48.43 \%(-100-553)$ in the resection and myolysis groups, respectively, after three-cycle GnRH analog therapy. The difference might also caused by different parameter of evaluation in which Wood used the number of symptom-free patients while we analyzed the percentage reduction in symptom scores.

Only dysmenorrhea showed statistically significant reduction after intervention in both groups. This may be due to the administration of GnRH analog for three cycles. Further studies are necessary for long-term observation, because as we know GnRH analog can not be administered for more than six cycles since this will result in climacteric symptoms. Wood found that $63 \%$ of patients were free from symptoms for two years, while $12 \%$ must underwent hysterectomy due to persistent severe symptoms or recurrence. ${ }^{8}$ Wood performed myolysis in two women with broad adenomyosis on the anterior wall and posterior uterus, in whom medical treatment had failed and resection was neither possible nor wanted by the patients. Two years after myolisi, both patients were free from menstrual pain and hemorrhage. ${ }^{8}$

It is worth to note that in this study no objective measurement was done to evaluate patient's symptoms. 
Symptoms were evaluated by subjective selfreporting, such that placebo effects were likely to occur.

\section{Comparison of reduction in adenomyosis volume between resection and myolysis}

Diagnosis of adenomyosis established by transvaginal ultrasonography was confirmed by histopathological examinations. Approximately 9 of 10 patients from the resection group who underwent histopathological examinations were found to have adenomyosis, while one patient had adenomyoma which could be removed satisfactorily due to its clearly defined border. This finding was consistent with some literature stating that transvaginal ultrasonography had high sensitivity $(87-98 \%)$ and specificity $(74-99 \%)$ as well as high positive and negative predictive values in diagnosing adenomyosis. ${ }^{25,7,11}$ In the present study, we did not perform histopathological examination in the myolysis group. For further study, it is advisable to conduct adenomyosis biopsy first prior to myolysis intervention.

We found that the mean volume of adenomyosis increased in both groups at the six-month evaluation. On statistical test, no significant difference was found between the two groups in adenomyosis volume increment.

In the resection group, of eight patients evaluated by ultrasonography, four were found to have volume reduction by approximately $3.7-100 \%$, while another four patients experienced increased volume by approximately $16-159 \%$. This may be due to the fact that the excision of unclearly-defined adenomyosis is technically difficult. As suggested by Wood, problems encountered in preserving the uterus are the uncertainty concerning the size of myometrium removed, except if the adenomyosis is clearly defined, such as adenomyoma, and whether normal pregnancy and delivery are still possible. ${ }^{8}$

The removal of myometrium in significant amount will create problems, such as reduced capacity of myometrium and uterus during pregnancy such that it may trigger abortion or premature birth; and the formation of scar tissue which can contain undetectable adenomyosis focus that may reduce the strength of stretch. The capacity of uterus expansion during pregnancy is more dependent on the increased plasticity, rather than elasticity. Nevertheless, the expansion capacity of the uterine myometrium and its supporting tissue makes it possible to perform myometrium excision in a certain amount without reducing the uterus capacity for normal expansion during pregnancy. ${ }^{8}$ Wood performed removal of myometrium by half size from the posterior myometrium in one patient whom became pregnant and gave birth by elective cesarean section in the $37^{\text {th }}$ week of gestation. ${ }^{8}$ In this study, only one patient who was observed formally until delivery, who was finally gave birth by cesarean section.

In the myolysis group, of nine patients undergoing ultrasonographic examination, three experienced volume reduction by $12.5 \%-99.8 \%$, while the remaining had increased volume by approximately $19.4 \%-553 \%$. One patient was pregnant after intervention and received GnRH hormonal therapy. Unfortunately, she experienced uterine rupture at eight month pregnancy, which was similar to Wood's study. This might happen because coagulation of adenomyosis would create the same effects as excision, in which myometrial tissue diminished while scar tissue were formed. ${ }^{8}$ The possibility of uterine rupture is associated with the formation of broad scar tissue after coagulation. It is advisable that myolysis is followed by sterilization in women with enough children, in view of the possible uterine rupture. ${ }^{8}$

However, adenomyosis itself can reduce the capacity of uterus by replacing normal myometrium and supporting tissue which can interfere the arrangements of muscular fibers and three-dimensional structure of collagen. In this way, the scar tissue which was formed after intervention constituted a separate factor. In Wood's study, adenomyosis was found in the location of uterine rupture in three patients. ${ }^{8}$ It appears that pregnancy after resection or myolysis still pose problems that should followed up cautiously. ${ }^{8}$

In addition to technical problems and the limitation of the tools used, it is necessary to pay attention to a number of initiating factors that may trigger and increase recurrence rate of the patients, such as status of estrogen, progesterone, and prolactin receptors as well as prostaglandin and endothelin, which was not observed in this study. ${ }^{13}$

As previously shown, the success rates of resection and myolysis in reducing subjective symptom scores were comparable. Similarly, the increase in adenomyosis volume was also similar. However, in myolysis, the possibility of rupture is greater because the damage of healthy myometrial tissue is greater than 
that in resection. ${ }^{8}$ Coagulation used in myolysis might also not as accurate as resection because of unpredictable, disturbed electrical conduction of abnormal tissue. ${ }^{8}$ Thus, myolysis is more appropriate for women aged above 40 years with enough parities who do not want any pregnancy anymore but wish to maintain their uterus or reject broad operation or hysterectomy. ${ }^{8}$

The findings of this study had not given enough evidence to provide guidance for managing symptomatic adenomyosis conservatively in the future because of the limitations in data, sample, and duration of the study. It is necessary to conduct further studies with an adequate number of subjects, objective data, and instruments. In addition, long-term observation is still essential in evaluating the effectiveness and side effects as well as the effects of the intervention on pregnancy and delivery. If persistent symptoms were found in women with enough parity, the most appropriate therapy for adenomyosis would be a total hysterectomy. ${ }^{8}$

\section{CONCLUSIONS AND RECOMMENDATIONS}

\section{Conclusions}

In conclusion, no significant differences were found in median reduction of menorrhagia and dysmenorrhea scores between the resection and myolysis groups. Reduction in pelvic pain score could not be evaluated because of the limited number of subjects having that symptom. Increase in adenomyosis volume was found in both groups after the intervention and GnRH ana$\log$ administration, but no significant difference was found in the mean of volume increment between the groups. Five patients were found to be pregnant, three from the resection group and two from the myolysis group. One case of uterine rupture was found in the myolysis group.

\section{Recommendations}

The findings of this study had not given enough evidence to provide guidance for managing symptomatic adenomyosis conservatively in the future because of the limitations in data, sample, and duration of the study. It is necessary to conduct further studies with an adequate number of subjects as well as objective data and instruments. In addition, long-term observa- tion is still essential in evaluating the effectiveness, side effects, and recurrence as well as the effects of the intervention on pregnancy and delivery. It is advisable not to perform myolysis in women who still want pregnancy. If persistent symptoms were found in women with enough parity, the most appropriate therapy for adenomyosis would be a total hysterectomy.

\section{Acknowledgments}

The authors indebted Dr. Nikmah Salamia Idris for reviewing the manuscript.

\section{REFERENCES}

1. Levgur M, Abadi MA, Tucker A,. Adenomyosis: symptoms, histology, and pregnancy terminations. Obstet Gynecol 2000;95:688-91.

2. Ferency A. Pathophysiology of adenomyosis. Human Reproduction Up date 1998;4:312-22.

3. Bergholt T, Ericsen L, Berend N, Jacobsen M, Hertz JB. Prevalence and risk factors of adenomyosis at hysterectomy. Human Reproduction 2001;16:2418-21.

4. Ota H, Igarashi S, Hatazawa J, Tanaka T. Is adenomyosis an immune disease? Human Reproduction up date 1998;4:360-7.

5. Arnold LL, Ascher SM, Schruefer JJ, Simon JA. The nonsurgical diagnosis of adenomyosis. Obstet Gynecol 1995; 86:461-5.

6. Atri M, Reinhold C, Mehio AR, Chapman WB, Bret PM. Adenomyosis: US features with histologic correlation in an vitro study. Radiology 2000;215:783-90.

7. Bazot M, Cortez A, Darai E, Rouger J, Chapler J, Antoine JM, Uzan S. Ultrasonography compared with magnetic resonance imaging for diagnosis of adenomyosis: correlation with histopathology. Human Reproduction 2001; 16:2427-33

8. Wood C. Surgical and medical treatment of adenomyosis. Human Reproduction up date 1998;4:323-6.

9. Fedele L, Bianchi S, Raffaelli R, Portuese A, Dorta M. Treatment of adenomyosis-associated menorrhagia with a levanorgestrel-releasing intrauterine device. Fertil Steril 1997;68:426-9.

10. Jacoeb TZ. Reseksi adenomiosis pada wanita infertil (pengalaman penanganan pada 67 kasus). Presented at the Annual Scientific Meeting of POGI; Malang 2002. p. 1-7.

11. Vercellini P, Cortesi I, Giorgi OD, Merlo D, Carinelli G, Crosignani PG. Transvaginal ultrasonography versus uterine needle biopsy in the diagnosis of diffuse adenomyosis. Human Reproduction 1998;13:2884-7

12. Brosens JJ, Souza NMD, Barker FG. Uterine junctional zone: function and disease. The Lancet 1995;346:558-60.

13. Mai KI, Yazdi HM, Perkins DG, Merlo DG and Parks W. Pathogenetic role of the stromal cells in endometriosis and adenomyosis. Histopathology 1997;30:430-42. 